\title{
基于健康行为素养培育的课堂教学模式的转变
}

\author{
王殿凯 \\ 常州市焦溪初级中学 \\ DOI:10.32629/jief.v2i10.2323
}

[摘 要] 初中体育是学校教学中的一项重要科目, 对于提高学生身体素质、提升综合能力、培养实践技能等方面都有积极的意义。但是, 在 教学中现, 传统的体育教学过于注重学生的体能训练, 却往往会忽略学生的健康行为培养, 这就要求教师在体育教学中要加强学生的健康行 为观教育, 这就需要初中教师综合实际探索, 培养学生吃苦耐劳的精神、激发学生的热情, 帮助学生树立正确的价值观。作为体育教师, 笔 者深知自身的责任重大, 时刻牢记要结合教学的实际上好每一堂课。本文主要就如何在初中体育教学中发展学生的健康行为观念做了简要的 分析。

[关键词] 初中; 体育教学; 学生; 健康行为; 观念

中图分类号: G633.96 文献标识码: A

对于每个人来说, 中学时期都是成长和学习的关键时期, 在这个阶 段中学生们养成他们的观念意识和行为习惯, 所以就需要体育教师完全 参与进教学指导中来, 帮助中学生可以认识到健康行为的重要性, 通过 加深他们这方面的观念来进行教学研究, 探索更加有效的教学策略。

\section{1 教师科学引导}

从本质上来讲, 初中体育教职人员是学生健康行为观念培养工作的 第一执行者, 初中体育教职人员只有科学且耐心的引导学生认知到健康 行为观念的树立对于其未来发展的重要性, 才能够保证每一位学生都能 够树立起健康行为观念。因此, 初中体育教职人员必须要做好科学引导 工作。为此, 首先, 初中体育教职人员必须要准确有效地认知到在初中 体育教学当中培养学生的健康行为观念对于提升学生体育学习安全性以 及身心健康水平的重要性, 以此来不断地提升学生对于健康行为观念的 认知度以及重视度。其次, 初中体育教职人员必须要将健康行为观念培 养渗入到思想当中准确有效地分析出学生的实际接受能力以及体质情 况, 然后对学生进行具有针对性的体育训练, 使学生能够直观的感知到 自身体质健康水平的提升, 进而保证其能够有效地了解到树立健康行为 观念对于其身心发展重要性。最后, 初中体育教职人员必须要科学合理 的对学生进行教学评价, 以正向引导为主, 明确学生的主体地位, 有效 地了解到学生在进行体育学习过程当中所做出的健康行为, 并给予及时 的表彰鼓励, 以此来增强学生的健康行为观念培养自信心以及积极性。

\section{2 结合体育训练培养学生的吃苦耐劳精神}

从实际角度出发, 学生只有具备较强的吃苦耐劳精神之后才能够坚 持不解的进行体育锻炼, 并严格的依照健康行为标准进行学习生活。因 此, 初中体育教职人员在实际进行体育教学活动期间必须要有效地结合 体育训练培养学生的吃苦耐劳精神。为此, 首先, 初中教职人员必须要 准确有效地了解到培养学生的吃苦耐劳精神是帮助学生树立健康行为的 关键步骤, 只有有效地提升学生的吃苦耐劳精神之后才能够保证学生能 够积极主动的树立起健康行为观念。其次, 初中体育教职人员在实际工 作期间必须要保证各项体育活动教学的持续性以及长效性, 由于培养学 生健康行为观念工作并不是短时间内可以完成的, 在这种情况下, 初中 体育教职人员必须要制定出具有长效性的体育教学方案, 并在教学的过 程当中有意识的告知给每一位学生要树立起吃苦耐劳的精神, 并在这种 精神的支持下, 坚持参加各项体育训练活动, 只有这样才能够保证自身 的体质健康水平能够得到有效的提升。最后, 初中体育教职人员必须要
保证训练方案的科学合理性, 集合每一位学生的体质健康基础水平, 为 其制定出具有针对性的训练方案, 这样可以在保证学生身心健康的同时, 不断地提升其体质健康水平。

\section{3 运用体育游戏教学法提升健康行为观念培养教学的趣味性}

学生对于体育学习的兴趣度, 在一定程度上直接决定着健康行为观 念培养工作的成效, 基于这一情况, 初中体育教职人员在实际工作期间, 必须要准确有效地落实体育游戏教学法, 以此来保证学生能够直观地感 知到健康行为观念培养教学活动的趣味性, 进而保证其能够积极努力地 参与到体育教学活动当中。为此, 首先, 初中体育教职人员必须要准确 有效地认知到趣味教学法的落实对于提升学生体育学习积极性的重要 性, 并在这种意识的引导下积极努力地搜集具有典型性以及实用性的游 戏教学案例, 并仿照案例当中的游戏活动开展各項趣味教学活动。其次, 要将良性竞争元素融入游戏活动当中, 在开展游戏活动之前告知学生要 在保证自身一起其他学生身心健康的基础上进行对抗竞争或团队竞争, 以此保证学生能够的健康行为意识能够得到有效的提升。

\section{4 结束语}

综上所述, 在素质教育背景下, 开展初中体育教学活动, 并通过该 项教学活动发展学生的健康行为观念已经成为初中体育教职人员的首要 工作。俗话说 “身体是革命的本钱”, 学生只有树立起健康行为观念, 严 格的依照健康行为标准进行学习运用, 才能够保证其拥有健康的体嵬, 进而保证其能够正常的进行学习生活。因此, 初中体育教职人员在实际 工作期间必须要将工作重心放到如何在初中体育教学中发展学生的健康 行为观念研究上, 结合初中生的实际特点以及初中体育健康行为教学的 需求, 制定出具有针对性的教学措施, 以此来保证每一位学生都能够树 立起健康行为观念, 进而保证学生能够严格地依照健康行为标准进行学 习以及体育活动。

\section{[参考文献]}

[1]曹风云.谈初中体育教学中如何培养学生健康的个性[J].教育科 学:引文版.2016(6):00181.

[2]左娟.浅谈初中体育教学中的学生心理健康教育[J].作文成功之 路:教育新干线.2016(10):10.

[3]罗艳.浅谈如何在初中体育教学中培养学生的创造性思维一一以 逸群初中为例[J].当代体育科技.2017.7(25):152. 